\title{
Kindergarten Teachers' Beliefs about the Relationship between Music and Early Learning
}

\author{
Roseanne L. Flores \\ Hunter College of the City University of New York, New York, NY, USA \\ Email: rflores@hunter.cuny.edu
}

How to cite this paper: Flores, R. L. (2018). Kindergarten Teachers' Beliefs about the Relationship between Music and Early Learning. Creative Education, 9, 1835-1842. https://doi.org/10.4236/ce.2018.912134

Received: August 2, 2018

Accepted: September 15, 2018

Published: September 18, 2018

Copyright (C) 2018 by author and Scientific Research Publishing Inc. This work is licensed under the Creative Commons Attribution International License (CC BY 4.0).

http://creativecommons.org/licenses/by/4.0/

\begin{abstract}
Music has been shown to be positively related to early learning and academic outcomes. Teachers' beliefs about how children learn and how they think about their own skills and competencies have also been shown to be linked to educational outcomes. The purpose of the present study was to examine kindergarten teachers' beliefs about the role of music in the curriculum and its relationship to classroom learning and educational outcomes. The methods involved surveying two teachers, one a classroom teacher, and the other a music specialist about the role of music in classroom learning. Qualitative results demonstrated that while both teachers believed music enhanced academic skills and memory, as well as promoted desirable behavior, the music teacher provided more direct links between music and other academic areas. The findings suggested that in general teachers believe that music plays a critical role in young children's early learning and educational experience, however, having training in music allows teachers to draw clear parallels between music and other areas of learning.
\end{abstract}

\section{Keywords}

Teachers, Beliefs, Music, Children, Early Learning

\section{Introduction}

According to the National Association of Music Education, music is critical to a well-rounded education for all children, with children benefiting from exposure to music early on their academic learning environments (NAfME, n.d.). In 1991 the NAfME put forth a position statement addressing the benefits of being exposed to music within early childhood education. The statement outlined the benefits of introducing all children from across diverse backgrounds, who may have diverse needs, to developmentally appropriate musical experiences as it 
could serve to address "the expressive, emotional, intellectual, social and creative needs of children," (NAfME, 1991). In 2015 the Every Student Succeeds Act (ESSA) was released replacing the No Child Left Behind Act (NCLB), (ESSA, n.d.). Unlike the NCLB Act, the new ESSA regulations called for music to be included as one of the core subject areas all children received during their academic careers to ensure they received an enriched educational experience (ESSA, n.d). In 2014, the NAfME released their revised standards for Pre-K- $8^{\text {th }}$ grade for General Music. The purpose of the 2014 Music Standards is to address music literacy by focusing on creating, performing, and responding (NAfME, n.d.). According to the new standards, children attending Pre-K and kindergarten should receive guidance to explore and experience music concepts. In addition, during the kindergarten year, as part of their music experience, children should learn to produce musical ideas with guidance from educators (NAfME, 2014). Thus, the new music standards align nicely with the ESSA regulations and address the need for all children to receive developmentally appropriate music education. That said, in order for children to receive a quality music education during the early years, they must have teachers who believe that a music education is as equally important to their education as the other areas of learning such as science, literacy, and mathematics. The question that arises then is: how do teachers' beliefs affect their perceptions about teaching?

\section{Overview of the Literature}

\subsection{Teachers' Beliefs and Academic Learning}

How teachers engage with the children around pedagogy is often embedded in their beliefs about teaching (Vartuli, 2005; Vartuli \& Rohs, 2009). According to Vartuli (2005) teachers' beliefs about their own abilities as well as their knowledge about how children learn has the potential to effect child outcomes, the classroom climate, behavior management as well as their satisfaction with the careers. In addition, Vartuli \& Rohs (2009) argue that when college students are learning to become "teachers" they often only see how teachers should perform, but do not focus on how they engage in reflective practice, decision making, or the day to day planning necessary for engaging children in the learning process, thereby rendering their overall beliefs about teaching inadequate. To ensure teachers can meet the needs of all children it is essential that they have an understanding about what factors affect their belief about teaching (Vartuli \& Rohs, 2009) as well as learn how to examine and reflect upon how these factors may affect their overall teaching thereby confirming their own biases and fitting into their schemas about teaching (Schirmer, Casbon, \& Twiss, 1997).

\subsection{Music and Academic Achievement}

Over the last several years the relationship between music and human development has been studied with respect to its influence on academic achievement (Hurwitz, Wolff, Bortnick, \& Kokas, 1975), cognitive development, (Rauscher, 2003), 
behavior (Hallam \& Price, 1998; Hallam, 2010) and emotional functioning (Costa-Giomi, 2004). More recently in a review of the literature (Young, 2016) has provided an overview of not only how music effects academic achievement during the later school years, but also has pointed out how music effects children during early childhood. As part of her review she highlights the advances that have taken place in the areas of theory with regard to how children learn and develop, the advances in new research methodologies, and the translation between research and practice in early childhood music education. That said, although the advances in research have shed some light on how music might enhance certain behaviors and skills, little is known about how such research findings are perceived by the general public, in particular by teachers for whom this information is particularly relevant.

\subsection{Teachers' Beliefs about Music and Academic Learning}

While recent research has demonstrated the added benefits of having music as a part of a child's early learning experience, unfortunately due to the many competing beliefs as to what constitutes school readiness and academic achievement, the inclusion of music as a necessary part of a child's overall learning experience has not always caught on. According to Koops (2018) in order for parents, administrators, policy makers, and other stakeholders to truly understand the necessity of having music as a part of a well-rounded curriculum, available to all children, it is critical for early childhood educators to be able to communicate about its added value. To that end early childhood educators must themselves believe that music is important for early learning. To date only a few studies have explored teachers' beliefs concerning the benefits of music and early learning (de I'Etoile, 2001; Cerniglia, 2013; Kim \& Kemple, 2011) with some of the results demonstrating that teachers' beliefs are often influenced by their own experiences as well as whether they see music as a "supplement" for enrichment or as a tool for learning (Kim \& Kemple, 2011). Unless teachers believe that music plays a critical role in education and development, and is therefore related to the broader curriculum, they are bound to minimize its importance and fail to adequately incorporate it into the curriculum. The purpose of the present study was to address this gap in the research literature by describing the beliefs and experiences of two kindergarten teachers, one a music specialist and the other a classroom teacher who were actively engaged in a music program over the course of an academic school year.

\section{Method}

\subsection{Participants}

The participants for this study were two Caucasian female teachers, one certified in music and education who taught the music sessions, and the other who was certified in art and education and was also the classroom teacher. 


\subsection{Procedure}

The research reported in this article was part of a larger study designed to examine the effects of music on young children's school performance in an urban community (Flores, 2006). As part of the original study, a random sample of kindergarten children attending an urban public school received music training which involved learning to play a keyboard from the music teacher two times per week for 45 minutes over the course of nine months. At the end of the school year, both the classroom and music teacher were asked to respond to an open ended survey in order to assess their beliefs about the relationship between music and academic success. The survey consisted of the following questions: 1). Do you think music enhances other academic areas? What areas do you think are enhanced? Please explain; 2). Do you think music enhances children's memory? Explain: 3). Do you think music effects behavior? Explain; 4). How do you see music relating to other areas of the curriculum?; 5). What do you see as the potential cost and benefits of having a music program in schools?

\section{Results}

\subsection{Qualitative Summaries of Responses}

\subsubsection{Beliefs about Music and the Enhancement of Academic Skills}

Both teachers indicated that they believed music enhanced a variety of academic areas such as, writing, math, reading and science. The kindergarten classroom teacher reported that she used music in her classroom to enhance all of the above mentioned areas as well as to begin the day because "it motivated the children to do the work and got them on task to work throughout the day." Moreover the classroom teacher stated that "the children often felt sad when they missed their morning music routine" thus showing how music might be related to the overall well-being of children. While the classroom teacher expressed a belief in the benefit of having music as part of the classroom routine, the music teacher expressed an even stronger belief about the relationship between music and academic skills asserting that "children learn all of their basic pre-reading, reasoning, coordination, and discrimination skills through music" thus suggesting that in addition to serving as a tool to motivate children music might also serve as a foundation area of study that could support other areas of learning.

\subsubsection{Beliefs about Music and Memory}

Both teachers indicated that in their experience music enhances memory. According to the classroom teacher, music involves repetition and association which leads to creativity, which in turn stimulates and enhances memory. According to the music teacher, music enhances auditory memory. In addition, from the music teacher's perspective for those children who are interested in advancing in music, learning music theory would help improve their memory.

\subsubsection{Beliefs about How Music Influences Behavior}

In response to the effect of music on behavior both teachers agreed that music 
had a positive effect on behavior. The classroom teacher asserted that, "without question, music could be calming as well as stimulating." Without music she felt the children were talkative, but when they were exposed to music they were more relaxed and attentive as well as excited, thus once again demonstrating how music had a positive effect on the overall well-being of the children. Similarly, the music teacher was also enthusiastic in her response. She stated, "Absolutely! When the children were involved in the listening of music-given a specific reason to listen for rhythms, specific instruments, reoccurring phrases or themes-they were extremely attentive." She also felt that, as the children developed these skills, and the music activities became more interesting and fun they would eventually start to listen for these patterns on their own.

\subsubsection{Music and the Early Childhood Curriculum}

In response to whether music influenced other academic areas both teachers agreed that music was related to other areas of the curriculum. However, the music teacher provided several concrete ways for how music could be integrated into all parts of the curriculum. For example, she pointed out, how music training could be incorporated into history by talking about the composers and the period of time in which they lived. How it could also be integrated into the math curriculum by counting and clapping rhythms, measures, phrases and note values. How it could be integrated into reading by teaching children to follow a music score-from left to right, top to bottom, and examining the pattern of notes. That through singing children could learn to recognize words through sight and sound. In addition, she described how music could also help young children with their fine motor skills, such as finger manipulation and how by singing songs in other languages children could be exposed to foreign languages. She also explained how children could be exposed to geography by learning about various countries, their native instruments, as well as how and why the instruments were developed. And finally, the music teacher described how children could relate music to art by drawing their feelings about music as well as actually making an instrument. In short, according to the music teacher the integration of music into the larger curriculum is endless!

\subsubsection{The Potential Cost and Benefits of Music Programs in Schools}

In response to the cost and benefits of having music programs in schools both teachers were passionate in their responses. They both agreed that music was not a luxury but rather necessary for the education of a well-rounded child. According to the classroom teacher "it would be a true disservice to exclude music from the academic curriculum. The 'Arts' are an integral part of one's complete education and experience in life." According to the music teacher "the costs may be high in terms of finance, but the benefits far outweigh the costs. The time spent in music class will benefit every child in every area of study."

In short, the overall responses presented in this section from both the music specialist and the classroom teacher provided evidence for the inclusion of music 
in early childhood classrooms to support positive cognitive, socioemotional, and behavioral outcomes for all children.

\section{Discussion and Educational Implications}

The findings from this study support the work of previous authors demonstrating the relationship between teachers' beliefs about music and classroom learning and school readiness skills (Kim \& Kemple, 2018). The results also showed that training in music tends to be associated with a stronger conviction about the relationship between music and learning, not only as a support and supplement, but also as a foundation for other areas of learning. Moreover, the findings from this study support the results of the Kim \& Kemple (2018) study which suggested that preservice teachers without expertise in music might benefit from receiving additional training in music to bolster their confidence so as to be able to teacher music in an early childhood classroom.

In short, this study provides additional evidence as to the importance of understanding how teachers view music and in particular, music instruction and the influence their views may have on whether they choose or don't choose, to incorporate music into the curriculum. Based on the responses of the teachers in present study it is evident that for them music has a major impact on the development of young children's academic skills, behavior, and socioemotional functioning. According to these teachers, young children's exposure to music is not just for enrichment purposes, but rather is integral to their overall functioning within the classroom.

As we strive to create learning environments that will produce the educated child of today and citizen of tomorrow, in line with the new ESSA regulations it would be wise to treat music as an integral part of the child's overall learning experience, rather than an extra-curricular activity. Although this study is limited in that it considers the responses of only two teachers, it nevertheless raises several points that are important when considering music instruction from the viewpoint of teachers and could have important implications for educational policy: 1) music instruction is important in and of itself in that it exposes children to a rich foundation that makes for a well-rounded and educated person; 2) music provides children with skills that can be applied across the curriculum, such as listening and memory skills; and 3) music can be used to teach many areas across the curriculum including geography, history, mathematics, science, language arts, and reading.

That said, as we work toward providing young children with access to a quality music education we must be mindful of the fact that classroom teachers are often overwhelmed when given the task of integrating music into their day to day teaching, and therefore must be provided with support to accomplish the task. As the results from this paper demonstrated it was "the music teacher" who suggested direct ways as to how one might incorporate music into the overall curriculum. Therefore, in addition to teaching music, it may be helpful for the 
music teacher to work directly with the classroom teacher scaffolding and demonstrating how the skills and techniques used in teaching music are related to the broader curriculum. Thus the music teacher can serve as a mentor, providing the classroom teacher with the resources needed to use music as a tool in order to link academic areas across the curriculum.

\section{Conclusion}

This qualitative study confirmed the results of previous research that demonstrated teachers' beliefs about music and its relationship to overall school success. Both the music specialist as well as the classroom teacher saw music as having a positive effect on the behavior, academic achievement, as well as socioemotional functioning of young children, in essence providing children with a positive context for learning. In short, as we continue to wait for additional research to be conducted that will allow us to address the causal links between music and cognitive development, academic achievement, behavior, and socioemotional functioning, how teachers view the role of music in relationship to early learning should not be overlooked. For once the larger questions are answered, the results of the research will need to be translated into classroom practice and teachers' attitudes and beliefs will need to be considered if the research is to have an impact on children's educational outcomes.

\section{Acknowledgements}

The author would like to thank the $42^{\text {nd }}$ Street Fund for its partial support of the project. The author would also like to thank the teachers who made this project possible.

\section{Conflicts of Interest}

The author declares no conflicts of interest regarding the publication of this paper.

\section{References}

Cerniglia, E. (2013). Preschool through Kindergarten: Musical Play in Early Childhood Classrooms: Taking It One Step Further. YC Young Children, 68, 68-73.

http://www.jstor.org/stable/ycyoungchildren.68.5.68

Costa-Giomi, E. (2004). Effects of Three Years of Piano Instruction on Children's Academic Achievement, School Performance and Self Esteem. Psychology of Music, 32, 139-152. https://doi.org/10.1177/0305735604041491

de l'Etoile, S. K. (2001). An In-Service Training Program in Music for Child-Care Personnel Working with Infants and Toddlers. Journal of Research in Music Education, 49, 6-20. https://doi.org/10.2307/3345806

Flores, R. (2006). The Effect of Arts Education on Urban Kindergarten Children's Academic Skills. Unpublished Manuscript, Department of Psychology, Hunter College of the City University of New York, New York.

Hallam, S. (2010). The Power of Music: Its Impact on the Intellectual, Social and Personal Development of Children and Young People. International Journal of Music Educa- 
tion, 28, 269-289. https://doi.org/10.1177/0255761410370658

Hallam, S., \& Price, S. (1998). Can the Use of Background Music Improve the Behavior and Academic Performance of Children with Emotional and Behavioral Difficulties? British Journal of Special Education, 25, 88-91. https://doi.org/10.1111/1467-8527.t01-1-00063

Hurwitz, I., Wolff, P., Bortnick, B., \& Kokas, K. (1975). Nonmusical Effects of the Kodaly Music Curriculum in Primary Grade Children. Journal of Learning Disabilities, 8, 45-52. https://doi.org/10.1177/002221947500800310

Kim, H. K., \& Kemple, K. M. (2011). Is Music An Active Developmental Tool or Simply a Supplement? Early Childhood Preservice Teachers' Beliefs about Music. Journal of Early Childhood Teacher Education, 32, 135-147.

https://doi.org/10.1080/10901027.2011.572228

Koops, L. H. (2018). Communicating the Importance of Music in Early Childhood. General Music Today, 31, 33-35. https://doi.org/10.1177/1048371317742111

National Association for Music Education (n.d.). Standards. https://nafme.org/my-classroom/standards/

National Association for Music Education. (1991). Early Childhood Education (Position Statement).

https://nafme.org/about/position-statements/early-childhood-education-position-state ment/

National Association for Music Education. (2014). 2014 Music Standards, PK-8 General Music. https://nafme.org/my-classroom/standards/core-music-standards/

Rauscher, F. H., \& ERIC Clearinghouse on Elementary and Early Childhood Education, C. I. (2003). Can Music Instruction Affect Children's Cognitive Development? ERIC Digest.

Schirmer, B., Casbon, J., \& Twiss, L. (1997). Diverse Learners in the Classroom Teacher Beliefs about Learning: What Happens When the Child Doesn't Fit the Schema? The Reading Teacher, 50, 690-692. http://www.jstor.org/stable/20201846

The Every Student Succeeds Act (ESSA) (n.d.). https://www.ed.gov/essa

Vartuli, S. (2005). Beliefs: The Heart of Teaching. YC Young Children, 60, 76-86. https://search.proquest.com/docview/197696272?accountid=27495

Vartuli, S., \& Rohs, J. (2009). Early Childhood Prospective Teacher Pedagogical Belief Shifts over Time. Journal of Early Childhood Teacher Education, 30, 310-327. https://doi.org/10.1080/10901020903320262 